\title{
Amerikalı Katoliklerin Değişimi
}

\section{İsmail DEMİREZEN ${ }^{1}$}

Özet

Son yapılan ampirik çalışmalar, Roma Katolik Kilisesi’nin öğretileri ile Amerikalı ruhban olmayan Katoliklerin bu öğretileri kabul etme istekleri arasında büyüyen bir uçurumun olduğunu ortaya çıkarmıştır. Bir meta-teori çalışması olarak bu makalede son yapılan ampirik çalışmalar incelenerek şu sorular cevaplanmaya çalışılacaktır: Roma Katolik Kilisesi ile Amerikalı ruhban olmayan Katolikler arasındaki çatışma ve uyuşmazlık konuları nelerdir? Katolikler neden Roma Katolik Kilisesi'nin öğretilerini kabul etme hususunda tereddüde düşmektedirler? Bu tereddüdün oluşmasında kültürel uyumun ve dünyevileşmenin katkıları nelerdir?

Anahtar Kelimeler: Amerikalı Katolikler, Dünyevileşme, Roma Katolik Kilisesi, Amerikan Toplumu

\section{Giriş}

Amerika Birleşik Devletleri’nde yaşayan Katolikler üzerine yapılan son çalışmalara göre, Roma Katolik Kilisesi’nin öğretileri ve otoritesi ile bu öğretilerin din adamı olmayan Amerikalı Katolikler tarafından kabulü ve/veya kabul isteği arasındaki uçurum giderek büyümektedir. Bu çalışmalara göre, günümüzde, her geçen gün artan sayıda ki Amerikalı

1 Doç. Dr., İstanbul Üniversitesi, İlahiyat Fakültesi, Din Sosyolojisi Bilim Dalı, idemirezen@hotmail.com 
Katolik, Roma Katolik Kilisesi’nin öğretilerini ve otoritesini sorgulamakta ve kabul etmemektedir. Bu makalede, biz, bir meta-teori çalışması olarak, Roma Katolik Kilisesi ile din adamı olmayan Katolikler arasındaki anlaşmazlıkların hangi konularda olduğunu araştıracağız. Daha da önemlisi, bu farklılıkların sebeplerini fenomenolojik ve rasyonel tercih yaklaşımlarıyla açıklamaya çalışacağız.

Bu mesafeyi ortaya koyan anket sonuçlarının yorumlanmasında ve sebeplerinin açılanmasında tarihsel analiz metodunu ve dünyevileşme teorilerini kullanacağız. Tarihsel araştırma metodu Amerikalı Katoliklerin sosyo-kültürel ve dini tarihsel arka planlarını incelememize imkân sağlayarak, Amerikan kültürü ile Amerikalı Katolikler arasındaki zihinsel ve fiziksel engellerin nasıl ortadan kalktığını anlamamıza yardımcı olacaktır. Bu fiziksel ve zihinsel duvarların yıkılmasının Amerikalı Katolikleri, Roma Katolik Kilisesi’nin bazı öğretilerini kabul etmemeye nasıl sürüklediğini açılamak için de fenomenolojik ve rasyonel dünyevileşme teorilerinden yararlanacağız. Böylece biz bu makalede, Amerikalı Katoliklerin, Roma Katolik Kilisesi’nin öğretilerinden farklı tutumlar takınmalarındaki başlıca sebebin Amerikan kültürü ile kendileri arasındaki fiziksel ve zihinsel duvarların yıkılması ile dünyevileşmeleri olduğu tezimizi ortaya koymaya çalışacağız.

Bu makale dört kısımdan oluşmaktadır. İlk kısımda son yapılan deneysel çalışmaların verilerinden yararlanılarak Amerikalı Katolikler ile Roma Katolik Kilisesi arasındaki çatışma konuları ve bu konuları etkileyen faktörler açıklanmaktadır. İkinci bölümde bu anlaşmazlıkların sosyo-kültürel ve dini sebepleri incelenmektedir. Üçüncü bölümde ise bu sebeplerin anlaşmazlıklara niçin sebep olduğunu açılayan kozalite (nedensellik) mekanizmaları belirtilmektedir. Son bölümde ise genel bir değerlendirme yapılmaktadır.

\section{Anlaşmazlıkların ve Çatışmaların Olduğu Temel Konular}

Anlaşmazlıkların ve çatışmaların olduğu temel noktaları, son zamanlarda yapılan iki anket çalışmasının verilerine dayanarak ortaya koymaya çalışacağız. Bu eserlerden ilki William V. D’Antonio ve diğerleri 
tarafından kaleme alınan, American Catholics: Gender Generation and Commitment isimli ampirik eser, diğeri ise, James Davidson ve diğerlerinin kaleme aldığ 1 The Search for Common Ground: What Unites and Divides Catholic Americans adlı eserdir. D’Antonio ve diğerlerinin çalışması 1987, 1993 ve 1999 yıllarında yapılan anket çalışmalarını içermektedir. Altı yıllık aralıklarla üç defa yapılan bu anket çalışmaları Amerikalı Katoliklerin değişimlerini ortaya koyma imkânı vermektedir. Davidson ve diğerlerinin çalışması ise D’Antonio ve diğerlerinin çalışmasını hem bir kontrol etme hem de gerekli olduğu yerlerde genişletme amaciyla incelenmiştir.

$\mathrm{Bu}$ iki yeni çalışma Amerikalı Katoliklerin kabulleri ile Roma Katolik Kilisesi'nin öğretileri arasındaki mesafeyi göstermeleri açısından önemli deneysel çalışmalardır. İlk çalışma Katolik inançlarını merkezi olan ve merkezi olmayan biçiminde ayrıma tabi tutarak Katoliklerin kabulleri ile Roma Katolik Kilisesi’nin öğretileri arasındaki mesafenin merkezi olmayan konularda olduğunu iddia etmiştir. İkinci çalışma ise Katolik inançlarını altı kategoriye ayırarak bu kategorileri Katoliklerin görüş birliğine göre bir sıralamaya tabi tutmuştur. Bu iki çalışmanın ortaya koyduğu gerçek ise Roma Katolik Kilisesi’nin öğretileri ile Amerikalı Katoliklerin kabulleri arasında çatışmaların ve anlaşmazlıkların olduğu gerçeğidir. Diğer çalışmaların da ışı̆̆ında bu çatışma ve anlaşmazlıkları şöyle sıralayabiliriz: cinsel etik, kürtaj, idam, bayanların ve evli erkeklerin din adamı olarak atanabilmeleri, Roma Katolik Kilisesỉnin toplumsal öğretileri ve daha demokratik bir kilise anlayışı.

\section{A. Temel Konular}

\section{Eşcinsellik, Doğum Kontrolü ve Evlilik Dışı Cinsel İlişki}

İlahi olarak belirlenmiş ve hikmetli bir şekilde düzenlenmiş doğa kanunlarından sapan ve soyun devamını sağlamayan herhangi bir cinsel aktivitenin ahlaki olarak yanlış olduğu varsayımını ileri sürerek, Vatikan, eşcinselliği, evlilik dışı her türlü ilişkiyi ve evlilikte dâhil her türlü cinsel ilişkide yapay doğum kontrolünü yasaklamaktadır (Dillon, 1999: 55). Fakat, son yapılan ampirik çalışmalarda yazarlar, ruhban 
olmayan Amerikalı Katoliklerle, Roma Katolik Kilisesi’nin bu konulardaki öğretilerinin arasında bir uyuşmazlık olduğunu ortaya koymuşlardır (Davidson, 1997: 47 ve D’Antonio, 2001: 85). Yazarların buldukları sonuçlara göre, Katoliklerin çoğunluğu ahlaki otorite açısından Roma Katolik Kilisesi’ni değil kendi vicdanlarını dikkate almaktalar. Bu eğilim İkinci Vatikan Konsülü öncesi ve sonrası bütün nesillerde geçerlidir. Ayrıca, kadınlar vicdanlarının sesine daha fazla kulak vermekteler (D’Antonio, 2001: 85).

\section{Kürtaj ve Ölüm Cezası}

Papa John Paul iki tane tamim (eniklikal) yayınlamıs ve bunlarda kürtaj ve ölüm cezasını tartışmıştır. Papa, bu tamimlerde kürtaj ve ölüm cezasını ahlaki görecelik bağlamında tartışarak hem kürtajı hem de ölüm cezasını kınamıştır. Fakat hem D’Antonio’nun hem de Davidson'nın çalışmaları Katoliklerin kürtaj konusunda Roma Katolik Kilisesi ile aynı fikirde olmadıklarını ortaya koymuştur (D’Antonio, 2001: 161; Davidson, 1997: 47). Bu durumu Davidson 'sonuççuluk' kavramıyla açıklamaya çalışmaktadır. Sonuççuluk kavramına göre, seksüel davranışlar bizzat kendileri doğru veya yanlış olmayıp şartlara veya kişiye getirdiğ $i$ sonuçlara göre doğru veya yanlış olarak kabul edilmektedir (Davidson, 1997: 47).Örneğin kişi doğum yaptığında işini bırakmak zorunda kalacak ve yaşam kalitesi düşecek ise bu durumda kürtaj yaptırması yanlış bir davranış olarak değerlendirilmemektedir.

\section{Bayanların ve Evli Erkeklerin Din Adamı Olarak Atanmaları}

Roma Katolik Kilisesi, bir doktrin olarak kadınların Roma Katolik Kilisesi'ne din adamı olarak atanmasına ve bir kural olarak da evli erkeklerin ruhban sınıfına dâhil olmasına karşı çıkmaktadır. Fakat D'Antonio'nun ve Davidson'nun çalışmalarına göre, Amerikalı Katolikler, bayanların din adamı olarak atanmasını; D’Antonio'nun çalışmasına göre ise, evli erkeklerin rahip olabilmelerini her geçen gün daha fazla desteklemekteler. Daha da ilginci, 1987, 1993 ve 1999'da yapılan üç ayrı ankete 
göre, Amerikalı Katolikler, kadınların papaz olarak atanmalarını ve evli erkeklerin papaz olabilmelerini en son yapılan ankette (1999) daha fazla desteklemiştir (D’Antonio, 2001: 112).

\section{Kilisenin Toplumsal Öğretileri}

Roma Katolik Kilisesi, Katoliklerden doğumdan ölüme kadar insan hayatına saygı temelinde toplumsal adaletin yerleşmesi için sorumluluk almalarını istemektedir. Amerikalı Katolikler ise Roma Katolik Kilisesi’nin bu konudaki isteklerine bağlllık göstermemektedir (D'Antonio, 2001: 98). Katolikler, prensipte Roma Katolik Kilisesi'nin fakirlere ve ihtiyaç sahiplerine ulaşma konusunda ki öğretisine katılmakla birlikte, bu çağrıyı kişisel olarak bir şeyler yapma olarak algılamamaktalar. (D’Antonio, 2001: 99 ve Davidson, 1997: 48).

\section{Katılım, Demokrasi ve Karar Mercii}

Ruhban sınıfından olmayan Amerikalı Katolikler, karar almada etkin olmayı ve Roma Katolik Kilisesi'nde daha fazla demokratik yapı istemektedir. İkinci Vatikan Konsülü sonrası kuşak Konsül öncesi kuşağa göre daha fazla katılım ve demokrasi istemektedir. Kiliseye bağlılık da katılım ve demokrasi isteklerini kamçılamaktadır çünkü daha dindar Katolikler Roma Katolik Kilisesi’nin aldığı kararlarda daha fazla etkin olmayı istemektedir (D’Antonio, 2001: 113-125).

\section{B. Bu Trendi Etkileyen Faktörler}

Roma Katolik Kilisesi’nin öğretileri ile Amerikalı Katoliklerin kabulleri arasındaki temel çatışma ve anlaşmazlık noktalarını belirttikten sonra, bu anlaşmazlıklarda etkin olan faktörleri incelememiz gereklidir. Temelde üç faktör bu temayülü etkilemektedir: kiliseye bağlllık, cinsiyet ve kuşak farklılığı. 
Bağlılık

Kiliseye daha fazla giden Amerikalı Katolikler, inançları hususunda Papa'nın otoritesini daha rahat kabul etmekte ve Roma Katolik Kilisesỉnin resmi öğretilerine daha az itiraz etmektedir. Mesela, Roma Katolik Kilisesi'ne önemli ölçüde bağlı olan Amerikalı Katolikler kadınların ve evli erkeklerin din adamı olmalarına daha tereddütlü bakmakta ve bunu onaylamamaktalar (D’Antonio, 2001: 22-23).

\section{Cinsiyet}

Amerikalı Katolik kadınlar kilisede daha aktif olmalarına rağmen, cinsel etik ve doğum kontrolü hususunda erkeklere göre Roma Katolik Kilisesi’nin öğretilerine daha az önem vermektedir. Kadınlar erkeklere nazaran infak etme, fakirler için zaman harcama ve fakir çocukların sağlık problemleriyle ilgilenme konularında daha isteklidir (D'Antonio, 2001).

\section{Kuşaklar}

İkinci Vatikan Konsülü öncesi kuşak ile Vatikan Konsülü kuşağı arasında büyük farklılıklar bulunduğu gibi İkinci Vatikan Konsülü kuşağ1 ile İkinci Vatikan Konsülü sonrası kuşak arasında da önemli farklılıklar bulunmaktadır. İkinci Vatikan Konsülü öncesi kuşak Roma Katolik Kilisesi’nin öğretilerine daha bağlı iken İkinci Vatikan Konsülü sonrası kuşak bu öğretilere daha az önem vermektedir (D’Antonio, 2001 ve Davidson, 1997).

\section{Katolik Kilisesi Öğretileri ile Amerikalı Katoliklerin Kabulleri Arasındaki Mesafenin Sebepleri}

D’Antonio ve diğerlerine göre, bu mesafenin oluşma sebebi, Amerikalı Katoliklerin bir cemiyet olma özelliğinden uzaklaşarak özgür bireyler olmalarıdır. Bu iddiadaki en zayıf nokta özgür birey tanımında yatmaktadır. Özgür birey özgür iradeyi gerekli kılmaktadır. Fakat biz 
biliyoruz ki özgür irade dediğimiz durum, mümkün olan davranış şekillerinden birini diğerleri arasından şuurlu veya bilinçsizce seçmektir (Hays, 1994: 62).

Mesela, kadınların ve evli erkeklerin din adamı olarak atanmaları hususunda Protestan fikrini (kadınların ve evli erkeklerin din adamı olarak atanabilmeleri) destekleyen bir Amerikalı Katoliği nasıl olurda özgür bir birey olarak kabul edebiliriz. Onun yaptığ 1 sadece Amerikan kültüründe münasip görünen bir değeri desteklemektir.

Bize göre Amerikalı Katoliklerin kabulleri ile Roma Katolik Kilisesỉnin öğretilerindeki bu kutuplaşmanın sebebi 1960 sonrası Roma Katolik Kilisesỉnin teolojik görüşlerindeki değişimler de dâhil olmak üzere toplumsal, ekonomik ve siyasi değişimlerin bir sonucu olarak Katoliklerin kuşatılmışlık hissiyatından kurtularak kendileri ve Amerikan kültürü arasında inşa ettikleri zihinsel ve fiziki duvarları yıkmaları ve böylece dünyevileşmeleridir.

Dean Hoge'nin de ifade ettiği gibi, 1850 sonrası Amerika'ya göç eden Protestanların dışındaki kilise mensupları, kendilerini bu düşman kültüründen korumak için kendi okullarını açmışlar, kendi gazetelerini çıkarmışlar, kendi derneklerini kurmuşlar ve kendi yetim hanelerini inşa etmişlerdir. Bu gettolaşma onlarda bir kuşatılmışlık hissiyatı oluşturmuştur. Fakat 1960'larda ki değişimler Amerikalı Katoliklerin bu kuşatılmışlık duygusundan kurtulmalarına imkân sağlamıştır (Hoge, 2008: 58).

Neden 1960 sonrası Amerikalı Katolikler kuşatılmışlık hissiyatından kurtulmuşlardır? Bunun en önemli sebepleri Kilisenin öğretilerinde değişiklik meydana getiren İkinci Vatikan Konsülü ve Amerikan toplumundaki ekonomik, siyasi ve sosyal değişimlerdir. Bu değişimler Amerikalı Katoliklerle Amerikan kültürü arasındaki sınırların kaybolmasına ve Katoliklerin dünyevileşmelerine olanak sağlamıştır.

\section{A. İkinci Ekümenik Vatikan Konsülü (1962-1965)}

İkinci Ekümenik Vatikan Konsülü veya Vatikan II, Roma Katolik Kilisesi’nin 21. yüzyıldaki ilk ekümenik konsülü olup Papa John XXIII 
tarafından 11 Ekim1962 tarihinde açılmış ve Papa Paul VI tarafından 21 Kasım 1965 tarihinde bitirilmiştir. Bu konsülde önemli kararlar alınmıştır. Özellikle ayinlerin yerel dillerde yapılmasına izin verilmesi ve diğer gruplara ilişkin kararlar Katoliklerin kiliseyi ve kendilerini alg1lamalarında değişiklik meydana getirmiştir.

İkinci Vatikan Konsülü, Roma Katolik Kilisesi’ni kurumsal veya organizasyon olarak değil, Tanrı'nın kulları olarak tanımlamıştır. Hans Kung Roma Katolik Kilisesi’nin kendini algılayışındaki bu değişikliği paradigma değişikliği olarak tanımlamıştır (Kung, 1989: 214). İkinci Vatikan Konsülü’nden önce Roma Katolik Kilisesi kendini bir kurum olarak kabul ediyordu. Bu anlayışa göre, Roma Katolik Kilisesi hiyerarşik bir tefekkür kurumu olarak algılanıyordu ve Roma'nın öğretisi hem sözde hem de güç olarak önceliğe sahipti (Dulles, 1987: 33). Bu algılayış şekli Katolik Reformasyonuyla (1563-1650) başlamış ilk dönem modernite ile devam etmiş (1650-1800) ve 19. yüzyılda doruğa ulaşmıştı.

Daha da önemlisi İkinci Vatikan Konsülü’nden önce Roma Katolik Kilisesi diğer Hıristiyanları dışlıyor ve onları heretik olarak değerlendiriyordu. İkinci Vatikan Konsülü diğer Hıristiyanları dışlayıcı pozisyonu terk etmiş ve Katoliklerin Protestanlarla birçok ortak noktalar1nın olduğuna vurgu yapmıştır. Ayrıca, diğer kiliselerde de doğruların olduğunu kabul etmiştir.

İkinci Vatikan Konsülü’nün getirdiği bu değişim Amerikalı Katoliklerin Amerikalı Protestanlara bakış açılarını değiştirmiştir. Bakış açısındaki bu değişiklik de Amerikalı Katoliklerin gettolarından çıkma ve Protestanlarla aralarında ördükleri fiziki ve zihinsel duvarları yıkma arzularını perçinlemiştir. Fiziki ve zihinsel duvarların yıkılması da bir taraftan Amerikalı Katoliklerin, Amerikan kültürüne uyumlarını sağlamış diğer taraftan da çoğulculuğun getirdiği bir ontolojik durum olarak ön kabullerini sorgulamalarına yol açmış ve böylece, dünyevileşme eğilimlerini artırmıştır. Çoğulculuğun dünyevileşmedeki etkilerini daha sonra ele alacağımız için şu anda detaylı bir şekilde inceleme yapmayacağız. 


\section{B. Sosyal ve Ekonomik ve Siyasi Değiş̧im}

1960'da Kennedy’nin Amerika Birleşik Devletleri Başkanı seçilmesinin hem Protestanlar hem de Katolikler üzerinde önemli etkileri olmuştur. Katolikler Kennedy'nin başkan seçilmesiyle birlikte kendilerini tam manasıyla Amerikalı hissetmişler ve zihinlerinde inşa ettikleri duvarları yıkmaya başlamışlardır. Protestanlar da Katolikler hakkında sahip oldukları ön yargıları sorgulamaya başlamışlar ve Katoliklere karşı daha hoş görülü davranış tarzlarını benimsemişlerdir (Hoge, 2008: 59).

1960'larda meydana gelen diğer sosyal olaylar da Katoliklerin ve Protestanların zihinlerindeki statükonun yıkılmasına yardımcı olmuştur. Afrika kökenli Amerikalıların ırkçı yaklaşımlara karşı çıkmaları ve sivil hareket oluşumuyla bazı haklar kazanmaları, Amerikan Yerlilerinin kendilerinden alınan toprakların bir kısmını geri almaları gibi toplumsal olaylar hem Katoliklerin hem de Protestanların zihin kalıplarını yıkmış ve onları diğer gruplara karşı daha hoşgörülü hale getirmiştir.

1960'larla birlikte Amerikan toplumunun refah seviyesi artmış ve bu toplum tüketim toplumu olmaya başlamıştır. Amerikalı Katolikler de bu eğilimden yararlanmış ve hem eğitim yönünden hem de ekonomik yönden Protestanların seviyesine çıkma imkânını elde etmişlerdir. Katoliklerin hem eğitim hem de ekonomik sermaye açısından sınıf atlamaları hem onları Amerikan kültürüne açık hale getirmiş hem de dünyevileşmelerini sağlamıştır. Sonuç olarak Katolikler de çevrelerindeki orta sınıf zihniyetini içselleştirmişlerdir. Katoliklerin doğum oranı ortalamaları ile Amerikan orta sınıfının doğum ortalaması aynı seviyeye gelmiş, Katolikler cinsellik gibi konularda Amerikan orta sınıfının zihniyetini benimsemişlerdir.

$\mathrm{Bu}$ değişimler Amerikalı Katoliklerin nasıl dünyevileştiklerini açıklamakla birlikte buna neyin sebep olduğuna cevap vermekte zorluk çekmektedir. Cevap için Amerikalı Katoliklerin dünyevileşmesine sebep olan kozalite mekanizmalarını bulmamız gereklidir. Tarihsel anlatıların tersine kozalite mekanizmaları gerçeklerin keşfinde kılavuzluk yapar, belirli alanlarda bilgi birikimini sağlar, yeni soruları ortaya çıartan 
anomalilerin keşfine imkan verir ve öyle şartlar oluşturur ki bu şartlar altında daha sağlam teoriler ortaya çıkar (Hechter, 1998: 785).

\section{Amerikalı Katoliklerin Dünyevileşmelerini Sağlayan Kozalite (Nedensellik) Mekanizmaları}

Amerikalı Katoliklerle Amerikan kültürü arasındaki zihinsel ve fiziki duvarların yıkılması, Amerikalı Katoliklerin dünyevileşmesini niçin sağlamıştır? Bu soruya verilecek iki ana cevap bulunmaktadır. Bunlardan birisi fenomenolojık bir yaklaşımla dini çoğulculuğun dünyevileşmeyi getirdiği cevabıdır. Diğeri ise, rasyonel tercih ekolünün ifade ettiği gibi, İkinci Vatikan Konsülü, Katoliklerin yaptıkları fedakârlıklardan ödün vermelerini sağlamış ve böylece Amerikalı Katolikleri cemaat olmaktan çıkartıp, genel dini bir grup haline getirmiştir.

\section{A. Fenomenolojık Yaklaşım}

Bu yaklaşıma göre, Katoliklerle Amerikan kültürü arasındaki fiziki ve zihni duvarların yıkılması dini çoğulculuğu ortaya çıkarmıştır. Bu dini çoğulculuk da Amerikalı Katoliklerin anlam dünyalarını oluşturan makul toplumsal yapının parçalanmasına sebebiyet vermiştir. Makul toplumsal yapıdan kastımız aynı anlam sistemini paylaşan kişiler arasında var olan özel sosyal süreçler veya etkileşimlerdir (McGuire, 2002: 37).

Peter Berger’in de ifade ettiği gibi, anlam sisteminin, varlığını devam ettirebilmek için makul toplumsal bir yapıya sahip olması gerekir. Anlam dünyası ne kadar çok makul toplumsal yapı ile desteklenirse, o kadar çok sağlam ve kalıcı olur. Yani, insanlar makul toplumsal yapı ile desteklenen anlam dünyasının doğal olduğunu, her zaman varlığını sürdürdüğunü, alternatifinin imkânsız olduğunu kabul eder ve gelecekte de varlığını sürdüreceğine inanırlar. Makul toplumsal yapı ile güçlenen anlam sistemlerinin zihinlerde daha da yer etmesi için meşrulaşması da gereklidir (Berger, 1967: 45-47).

Meşrulaşmadan kastımız toplumsal düzeni anlamlı hale getiren ve açıklamaya yardımcı olan toplumsal olarak nesnelleştirilmiş bilgilerdir 
(Berger, 1967: 29). Meşrulaşma bazı zaruriyetlerin ve bazı bilgilerin daha genel normlara ve geçerli addedilen bilgilere referans verilmesiyle gerçekleşir. Meşrulaştırma süreci pratik bir zorunluluğa normatif bir değer katar, kurumsal düzene de idraksal bir geçerlilik verir. Böylece pratik bir zorunluluk bir norma ve pratik bir bilgi de evrensel bir doğruya dönüşür (Munch, 1987: 160).

Anlam dünyası ile pratik hayat arasındaki ilişkiyi ise dini ritüeller oluşturmaktadır. Berger’in söylediği gibi, dini ritüeller hatırlatma sürecindeki en hayati enstrümanlardır. Dini ritüeller bunları yerine getirenlere tekrar ve tekrar gerçekliğin tarifini hatırlatır (Berger, 1967: 40).

Meşruiyet araçları ile desteklenmiş, ritüellerle perçinlenmiş anlam dünyası diğer anlam dünyaları ile karşılaştığı zaman ve diğer anlam dünyaları ile birlikte yaşamak zorunda kaldığında eski gücünü kaybeder. Daha önce hiçbir alternatifi olmadığı için çok tabii görünen, sorgulanmayan ve kabullenilen bu yapı diğer anlam dünyaları ile birlikte yaşamaya başladıktan sonra o toplumdaki bireylerin alternatiflerinden biri haline gelmektedir. Bireylerin seçimine kalmış ve bireylerin vicdanına hapsedilmiş bir anlam dünyasının bireyler üzerindeki etkisinin azalması kaçınılmazdır. Berger'in de ifade ettiği gibi, din tarafından sunulan anlam dünyası nesnelliğini kaybeder ve göreceli hale gelir. Anlam dünyaları öznel hale geldiği için de anlam dünyasının sunduğu gerçeklikler bireylerin özel hayatının bir parçası haline gelir ki bu durum, anlam dünyalarının aşikâr nesnelliğinin kaybıdır (Berger,1967: 152).

Daha önce de ifade ettiğimiz gibi, İkinci Vatikan Konsülü’ndeki değişiklikler ve Amerikan toplumundaki toplumsal, siyasi ve ekonomik değişimler, Amerikalı Katoliklerin diğer mezhep ve din mensuplarıyla aralarındaki zihinsel ve fiziki duvarları yıkmalarına sebebiyet vermiştir. Bu duvarların yıkılması da diğer anlam dünyalarının Katolik anlam dünyasına ve makul toplumsal yapısına meydan okumasını sağlamıştır. Amerikalı Katolikler için Katolik anlam dünyası diğer anlam dünyaları arasında bir seçenek haline gelmiştir. Seçenek haline gelmesi de Katolik anlam dünyasının Katolikler arasındaki aşikâr nesnelliğini kaybettirmiştir. Daha da önemlisi, artık Katolik anlam dünyası Katoliklerin 
öznel seçimi haline gelmiştir. Bu durum doğal olarak Roma Katolik Kilisesỉnin otoritesinin ve öğretilerinin sorgulanmasını beraberinde getirmiştir. Bu sorgulama Roma Katolik Kilisesi ile Amerikalı Katoliklerin tutumları arasındaki farklılıkların oluşmasını sağlayan temel nedenlerden birisidir.

Böylece, 'kafeterya katoliklik' kavramı ortaya çıkmıştır. Bu kavram Roma Katolik Kilisesi’nin öğretilerine bağlı kalmayıp istediği anlam dünyasından istediği sembolleri ve ritüelleri seçen ve uygulayan Katolikler için kullanılmaya başlanmıştır. Jerome Baggett yaptığ 1 mülakatlarda Katoliklere bu kavramın kendileri için ne anlama geldiğini sormuş ve verilen cevaplar doğrultusunda bu kavramın artık olumsuz bir anlam taşımadığı sonucuna ulaşmıştır (Baggett, 2009: 74). Mülakatlardan iki tanesini Katoliklerin bakış açılarını kendi dillerinden ifade etmek için aktarıyoruz.

Bir Katolik, kafeterya Katolikliğe bakış açısını şöyle ortaya koymaktadır: "Ben kesinlikle kafeterya Katoliğim. Seçmem gerekiyor. Şayet çalı fasulyesini sevmiyorsam, onu yemek zorunda değilim. Tatlı yemek istiyorsam, tatlı yerim.” Diğer bir Katolik de bu kavrama karşı tavrını şöyle belirtmektedir: "İnsanlar, dini, açık büfe olarak betimledikleri zaman onlara bir itirazım yok. İnsanların hiçbir şey almamalarından bazı şeyler almalarını tercih ederim. Benim tecrübem kafeterya Katolikliğin insanların iştahını açtığı yönündedir. İnsanlar açık büfede daha rahattırlar ve bundan dolayı buna zaman ayırabilir ve kendi zevklerine uygun olanı keşfedebilirler (Baggett, 2009: 74)."

Çok kültürlü toplumlarda yaşayan çoğu dini grubun başına gelen Katoliklerin de başına gelmiş, Katolik anlam dünyası kişisel bir seçenek halini almıştır. Yani dinin sağladığı anlam dünyası bütün toplumu kucaklayan kutsal bir hava sahası olmaktan çıkmış, bireylerin kendi ihtiyaçlarına göre ayarlamalar yapılabildikleri kutsal bir şemsiyeye dönüşmüştür. Altında inançlarının bir anlam kazandığı kutsal şemsiye çok kültürlülüğün ve modernizmin bir sonucu olarak ortaya çıtı (Smith and Emerson, 1998). Birçok kişi bu kutsal şemsiyelerin altında göreceli anlam dünyalarını ve dindarlıklarını devam ettirebildiler. Amerikan 
toplumunda yaşayan bir Protestan veya bir Yahudi, kutsal şemsiyelerinin altında dini inançlarını devam ettirebilme imkânını bulmuştur.

Fakat Amerikalı Katoliklerin durumunu kutsal şemsiye misaliyle açıklamak da imkânsız çünkü onlar birçok konuda kendi kiliselerinin öğretilerinin karşısında yer almaktadır. Amerikan toplumuyla aralarındaki sınırlar kalkınca Amerikalı Katoliklerin anlam dünyaları zayıflamakla kalmamış aynı zamanda dünyevileşmişlerdir. Başta sundugumuz ampirik veriler de bunu ispat etmektedir.

\section{B. Rasyonel Tercih Bakış Açısı}

$\mathrm{Bu}$ bakış açısına göre ise Amerikalı Katolikler dünyevileşmişlerdir çünkü özellikle İkinci Vatikan Konsülü Amerikalı Katoliklerin belirgin fedakârlıklarından ödün ve taviz vermelerini sağlamış ve böylece Amerikalı Katolikler Amerikan toplumunda bir cemaat olma özelliklerini kaybedip bu toplumun genel bir dini grubu haline gelmişlerdir. $\mathrm{Bu}$ akımın kurucularından Rodney Stark'a göre, Katolik olmanın belirgin özelliği olan fedakârlık İkinci Vatikan Konsülü ile birlikte terkedilmiştir. Bu da beraberinde Amerika'da Katolikliğin güç kaybetmesine sebebiyet vermiştir. Stark'a göre, Katoliklik böylece bir cemaat olmaktan çıkmış orta bir dini grup haline gelmiştir (Stark, 1992: 257-261).

Rasyonel Tercih Yaklaşımı, din ile insanların etkileşimlerini piyasa mekanizmasına benzettiği için market teori olarak adlandırılmaktadır. Bu ilk başta Stark ve Roger Finke tarafından ileri sürülmüştür. Stephen Warner'e göre rasyonel tercih teorisi bir paradigma değişikliğini de beraberinde getirmektedir. 19. yüzyılın başlarında dünyevileşme teorileri Avrupa örneği üzerine yoğunlaşırken Amerika örneğini ihmal etti. Fakat Amerikan örneği dünyevileşme teorilerine uymayan anomalilelerin çoğalmasına sebebiyet verdi. Bu anomaliler o kadar çoğaldı ki sonuç olarak Rasyonel Tercih Yaklaşımı ortaya çıktı (Warner 1993).

Stark'a göre, din ekonomisinden kasit bir toplumda meydana gelen bütün dini faaliyetlerdir. Bu faaliyetler şu andaki ve potansiyel müritleri, mürit çekmek isteyen ve bağlıları olan dini organizasyonları ve 
bu organizasyonlar tarafından sunulan dini kültürü kapsamaktadır (Stark, 2000: 193). Bu tarifte de gördüğümüz üzere, bu yaklaşıma göre, din ekonomisi piyasa ekonomisine benzemektedir. Din ekonomisinde de müşteriler, markette bir yer kaplayan firmalar ve bu firmalar tarafından üretilen ürünler bulunmaktadır. Bu modelin mantı̆̆ını şu şekilde özetleyebiliriz: Düzenlenmemiş market, dini çoğulculuğa sebebiyet verir, dini çoğulculukta dini gruplar arasında rekabete yol açar, dini gruplar arasındaki rekabet de ürünlerin liberal veya radikal öğretiler gibi özelleşmesini sağlar ve bazı gruplar daha fazla fedakârlık ister ki fazla fedakârlık da daha yüksek dini katılımı sağlar (Yamane, 1997: 111). Düzenlenmemiş markette, görünmeyen el sayesinde uzun zamanda dini marketin çeşitliliği toplumun çeşitliliğine tekabül eder ki bu da dini hayatın canlanması ve artması anlamına gelmektedir.

$\mathrm{Bu}$ yaklaşım bazı dini grupların güç kaybetmesini, çevresindeki dünyevi kültürle olan ilişkisi ile açıklamaktadır. Bu yaklaşıma göre, bir dini grup, çevresindeki dünyevi kültüre ne kadar çok taviz verirse o kadar çok güç kaybeder. Aynı şekilde, Amerikalı Katoliklerin, kilisenin öğretilerine fazla önem vermemelerinin sebeplerinden birisi, İkinci Vatikan Konsülünün dünyevi kültüre çok fazla taviz vermesi ve bunun sonucu olarak da Amerikalı Katoliklerin dünyevileşmeleridir.

\section{Sonuç}

Bu makalede ilk olarak Amerikalı Katoliklerin, Roma Katolik Kilisesi’nin öğretileri hakkındaki tutumlarını inceledik. Son yapılan ampirik çalışmaları incelediğimizde, Amerikalı Katoliklerin tutumları ile Roma Katolik Kilisesi’nin bazı öğretileri arasında farklılıklar olduğunu fark ettik. Cinsel etik, kürtaj, idam, bayanların ve evli erkeklerin din adamı olarak atanabilmeleri, Roma Katolik Kilisesi’nin toplumsal öğretileri ve daha demokratik bir kilise anlayışı konularında Roma Katolik Kilisesi’nin öğretileri ile Amerikalı Katoliklerin tutumları arasında önemli farklılıklar bulunmaktadır.

$\mathrm{Bu}$ farklılıkların sebeplerini ikinci bölümde bulmaya çalıştık. Bize göre bunun temel sebebi 1960'lı yıllarda gerçekleșen toplumsal, ekonomik, 
dini ve politik değişimler sonucu bir taraftan Amerikalı Katoliklerin Amerikan kültürü ile kendileri aralarında örmüş oldukları fiziksel ve zihinsel duvarları yıkmaları ve diğer taraftan da Amerikalı Protestanların önyargılarını terk etmeleriyle Katolikleri kabul etmeleridir. Politik olarak Amerikan tarihinde ilk defa 1960'da bir Katolik olan Kennedy başkan seçilmiştir. Ekonomik olarak Amerika orta sınıfının refah seviyesi artmış ve birçok Katolik bu refahtan pay almıştır. Sosyal olarak sivil hareket sonucunda ırkçı düşünceler ve davranışlar demode olmuştur. Dini olarak ise İkinci Vatikan Konsülü diğer mezheplerde de hakikat olduğunu kabul etmiş ve diğer din ve mezheplerle diyalog yollarını açmıştır. Bütün bu değişimler Amerikalı Katolikleri gettolarından çıkarmış ve onların Amerikan kültürüne uyum sağlamalarına imkân vermiştir. Fakat bu durumla Amerikalı Katoliklerin Roma Katolik Kilisesi öğretilerine karşı çıkmaları arasında nasıl bir bağlantı bulunmaktadır?

$\mathrm{Bu}$ bağlantıyı hem fenomenolojık yaklaşımı hem de rasyonel tercih teorisini kullanarak açıklamaya çalıştık. Fenomenolojik yaklaşım açısından, Amerikalı Katolikler, Amerikan kültürü ile kendileri arasındaki duvarları yıktıklarında, Katolik anlam dünyası onlar için diğer anlam dünyaları ile birlikte bir seçenek haline geldi. Daha önce ise Katolik dünya görüşü ve inançları tek ve yegâneydi. Bu değişim Katolik kimliği ve inançlarının gücünü ve etkisini azalttı. Rasyonel tercih teorisine göre ise, dünyevi kültür ile kendi kültürleri arasındaki gerilim azaldığı için Amerikalı Katolikler, Roma Katolik Kilisesi’nin öğretilerine karşı çıkmaya başladılar.

\section{Kaynakça}

Berger, Peter. 1967. The Sacred Canopy, Doubleday, Garden City, New Jersey.

Baggett, Jrome P. 2009. Sense of the Faithful: How American Catholics Live Their Faith. Oxford University Press: New York.

D’Antonio, William V., James D. Davidson, Dean R. Hoge, Katherine Meyer. 2001. American Catholics: Gender, Generation, and Commitment, Alta Mira Press, Walnut Creek, CA. 
Dean R. Hoge. 2008. "Interpreting Change in American Catholicism: The River and Floodgate." In Review of Religious Research: Special 50th Anniversary Edition 50: 55-65.

Dillon, Michele. 1999. Catholic Identity: Balancing Reason, Faith, and Power. Cambridge, U.K. ; New York : Cambridge University Press.

Davidson, James D, Andrea S. Williams, Richard A. Lamanna, Jan Stenftenagel, Kathleen Maas Weigert, William J. Whalen and Patricia Wittberg. 1997. The Search for Common Ground: What Unites and Divides Catholic Americans. Huntington, Ind.: Our Sunday Visitor.

Dulles, Averi. 1987. Models of the Church. Daubleday, New York.

Finke, Roger and Rodney Stark. 1992. The Churching of America, 17761990: Winners and Losers in our Religious Economy. New Brunswick, N.J.: Rutgers University Press.

Hays, Sharon. 1994. "Structure and Agency and the Sticky Problem of Culture." In Sociological Theory 12: 57-72.

Kiser, Edgar and Michael Hechter. 1991. "The Role of General Theory in Comparative-historical Sociology." In American Journal of Sociology 97: 1-30.

Kung, Hans ve David Tracy (edit).1989. Paradigm Change in Theology: A Symposium for the Future. New York, Crossroad.

McGuire, Meredith B. 2002. Religion, the Social Context. Wadsworth Thomson Learning.

Munch, Richard. 1987. Theory of Action: Towards a New Synthesis Going Beyond Parsons. New York: Routledge\& Kegan Paul Inc.

Smith, Christian and Michael Emerson. 1998. American Evangelicalism: Embattled and Thriving, University of Chicago Press.

Stark, Rodney and Roger Finke. 2000. Acts of Faith, University of California Press, Berkeley.

Warner, Stephen. 1993. "Work in Progress toward a New Paradigm for the Sociological Study of Religion in the United States", American Journal of Sociology, Mar1993, Vol. 98 Issue 5: 1044-93. 


\title{
Transformation of American Catholics
}

\begin{abstract}
Recent studies on American Catholics have revealed a growing gap between the claims of teaching authority by church leaders and the willingness to accept such authority by the laity. In this paper, as a meta-theory work, we will try to address following questions according to recent studies: What are the major areas of conflict and dissent? Why do American Catholics hesitate to accept the claims of teaching authority by Roman Catholic Church? What are the contributions of American Catholics' integration and secularization to this hesitation?
\end{abstract}

Key Words: American Catholics, Secularization, American Society, Roman Catholic Church 